\title{
ICA512 RESP18 homology domain is a protein-condensing factor and insulin fibrillation inhibitor
}

Received for publication, January 22, 2019, and in revised form, April 9, 2019 Published, Papers in Press, April 12, 2019, DOI 10.1074/jbc.RA119.007607

Pamela L. Toledo ${ }^{\ddagger \S 1}$, Juha M. Torkko ${ }^{\ddagger \S \uparrow|| * * 1}$, Andreas Müller ${ }^{\uparrow|| * *}$, Carolin Wegbrod $^{\uparrow|| \mid * *}$, Anke Sönmez ${ }^{\uparrow|| * *}$, Michele Solimena ${ }^{\mathrm{q} \| * * \neq \neq 2}$, and Mario R. Ermácora ${ }^{\ddagger £ 3}$

From the ${ }^{\ddagger}$ Grupo de Biología Estructural y Biotecnología, Universidad Nacional de Quilmes, 1876 Bernal, Buenos Aires, Argentina, the ${ }^{\S}$ IMBICE, CONICET-CIC-Universidad Nacional de La Plata, B1906APO La Plata, Buenos Aires, Argentina, the "Department of Molecular Diabetology, University Hospital and Faculty of Medicine, TU Dresden, 01307 Dresden, Germany, the llPaul Langerhans Institute Dresden of the Helmholtz Center Munich at the University Hospital and Faculty of Medicine, TU Dresden, 01307 Dresden, Germany, the **German Center for Diabetes Research (DZD e.V.), 85764 Neuherberg, Germany, and the ${ }^{\neq \neq}$Max Planck Institute of Molecular Cell Biology and Genetics, 01307 Dresden, Germany

Edited by Jeffrey E. Pessin

Type 1 diabetes islet cell autoantigen 512 (ICA512/IA-2) is a tyrosine phosphatase-like intrinsic membrane protein involved in the biogenesis and turnover of insulin secretory granules (SGs) in pancreatic islet $\boldsymbol{\beta}$-cells. Whereas its membrane-proximal and cytoplasmic domains have been functionally and structurally characterized, the role of the ICA512 N-terminal segment named "regulated endocrine-specific protein 18 homology domain" (RESP18HD), which encompasses residues 35-131, remains largely unknown. Here, we show that ICA512 RESP18HD residues 91-131 encode for an intrinsically disordered region (IDR), which in vitro acts as a condensing factor for the reversible aggregation of insulin and other $\boldsymbol{\beta}$-cell proteins in a $\mathrm{pH}$ and $\mathrm{Zn}^{2+}$-regulated fashion. At variance with what has been shown for other granule cargoes with aggregating properties, the condensing activity of ICA 512 RESP18HD is displayed at a $\mathrm{pH}$ close to neutral, i.e. in the $\mathrm{pH}$ range found in the early secretory pathway, whereas it is resolved at acidic $\mathrm{pH}$ and $\mathrm{Zn}^{2+}$ concentrations resembling those present in mature SGs. Moreover, we show that ICA512 RESP18HD residues 35-90, preceding the IDR, inhibit insulin fibrillation in vitro. Finally, we found that glucose-stimulated secretion of RESP18HD upon exocytosis of SGs from insulinoma INS-1 cells is associated with cleavage of its IDR, conceivably to prevent its aggregation upon exposure to neutral $\mathrm{pH}$ in the extracellular milieu. Taken together, these findings point to ICA512 RESP18HD being a condensing

This work was supported by funds (to M. S.) from the German Center for Diabetes Research (DZD) and from the Innovative Medicines Initiative 2 Joint Undertaking under Grants 115881 (RHAPSODY) and 115797 (INNODIA). This work was also supported by the Swiss State Secretariat for Education, Research and Innovation (SERI) under contract number 16.0097. The authors declare that they have no conflicts of interest with the contents of this article.

This article contains Figs. S1-S7 and Methods S1.

${ }^{1}$ These authors contributed equally to this work.

${ }^{2}$ To whom correspondence may be addressed: Dept. of Molecular Diabetology, University Hospital and Faculty of Medicine, Fetscherstrasse 74, 01326 Dresden, Germany. Tel.: 49-351-796 36612; E-mail: michele.solimena@tudresden.de.

${ }^{3}$ Recipient of funds from the Universidad Nacional de Quilmes, CONICET, and the Agencia Nacional de Promoción Científica y Tecnológica (PICT2016 0584), Argentina. To whom correspondence may be addressed: Universidad Nacional de Quilmes, Roque Sáenz Peña 352 (1876) Bernal, Buenos Aires, Argentina. Tel.: 54-114-365-7100 (Int. 5642); E-mail: ermacora@ unq.edu.ar. factor for protein sorting and granulogenesis early in the secretory pathway and for prevention of amyloidogenesis.

Receptor-type protein-tyrosine phosphatases (RPTPs) ${ }^{4}$ are transmembrane proteins involved in signaling pathways (1). ICA512 (also known as IA-2, PTP35, or PTPRN) and phogrin (also known as IA-2 $\beta$, IAR, ICAAR, or PTPRN2) are R8 subtype RPTPs mainly expressed in peptide hormone-secreting endocrine cells and neurons, where they are enriched in the membrane of secretory granules (SGs) and large dense-core vesicles, respectively $(2,3)$.

In mice, genetic deletion of ICA512, phogrin, or both results in mild glucose intolerance and decreased glucose-responsive insulin secretion $(4-6)$. A large body of evidence suggests that both proteins are involved in the biogenesis and turnover of insulin SGs in pancreatic islet $\beta$-cells (7-9). Accordingly, their depletion, either alone or in combination, strongly reduces, but does not abolish, insulin SG stores in vitro and in vivo.

ICA512 and phogrin have a large luminal ectodomain, a single-pass transmembrane segment, and a cytoplasmic and catalytically-impaired protein-tyrosine phosphatase (PTP) domain (Fig. 1A) (10). During SG maturation, the ICA512 ectodomain is cleaved by furin-like proprotein convertases, generating an N-terminal fragment (ICA512 NTF; residues 35-448) and a transmembrane fragment (ICA512 TMF; residues 449-979) (3).

The cytoplasmic domain of ICA512 TMF interacts with the cortical cytoskeleton via $\beta 2$-syntrophin, an adapter protein involved in the tethering of SGs to F-actin, thereby regulating insulin SG mobility and exocytosis (9, 11, 12). Furthermore, through a still unidentified signaling pathway, ICA512 modulates gene expression of the F-actin modifier villin, another factor for tight control of insulin SG mobility and exocytosis (13).

\footnotetext{
${ }^{4}$ The abbreviations used are: RPTP, receptor-type protein-tyrosine phosphatase; ICA512, islet cell antigen 512; SG, secretory granule; PTP, proteintyrosine phosphatase; NTF, N-terminal fragment; TMF, transmembrane fragment; $M P E$, membrane proximal ectodomain; Resp18, regulated endocrine-specific protein 18; RESP18HD, RESP18 homology domain: LLPT, liquid-liquid phase transition; IDR, intrinsically disordered region; ThT, thioflavin T; TQ2, turquoise 2; TEM, transmission EM.
} 
A

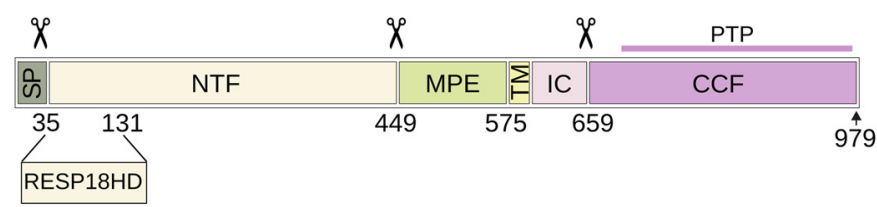

B ICA512 RESP18HD

Resp18

Phogrin RESP18HD

60 70 80 50 VSAHGCLFDRRLCSHLEVCIQ TSAH $\ldots \ldots \ldots \ldots \ldots$ PGRLGCLLEEGLCGASEACVN

DGLFGQCQVGVGQARPLLQVTSPV · LQRLQGVLRQLMSQG D $\cdots$ GQDQVGVGQLWPLQGFATPV · FQHLQVVLQQIIPQG DGVFGRCOKVPAMDFYRYEV ·SPVALQRLRVALQKLSGTG

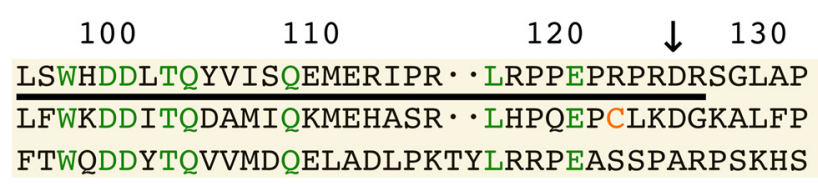

Figure 1. ICA512 processing and ICA512 RESP18HD sequence. $A$, SG luminal segment of ICA512 (UniProtKB Q16849) comprises residues 1-575 and includes a signal peptide (SP), the NTF, and the MPE. The transmembrane domain (TM) comprises residues 576-600. The cytoplasmic region, residues $601-979$, is made of the juxtamembrane intracellular domain $(I C)$ and the cytoplasmic cleaved fragment (CCF). Most of cytoplasmic cleaved fragment corresponds to the pseudo-phosphatase (catalytically inactive) domain (PTP), from which the entire protein is named. Scissors mark well-characterized processing sites. Convertase-mediated cleavage at residue 448 generates the transmembrane fragment (ICA512 TMF, residues 449-979, corresponding to MPE-TM-IC), which is transiently inserted into the plasma membrane upon exocytosis. ICA512 RESP18HD constitutes the N-terminal portion of ICA512 NTF. B, sequence alignment of ICA512 RESP18HD, Resp18 (UniProtKB Q5W5W9), and phogrin RESP18HD (UniProtKB Q92932). Identical residues and cysteine residues are indicated in green and orange, respectively. An ICA512 RESP18HD C-terminal cleavage site between Arg-124 and Asp-125 in ICA512 RESP18HD (this work) is indicated with a down arrow. Most of the IDR accounting for ICA512 RESP18HD aggregation activity (this work) is the product of exon-4, which encodes for ICA512 residues 94-126 (underlined).

Transient insertion of ICA512 TMF in the plasma membrane upon insulin SG exocytosis is coupled to the cleavage of its cytoplasmic tail by $\mathrm{Ca}^{2+}$-dependent calpain (12) and the generation of a cytoplasmic fragment that enhances STAT5-mediated transcription of SG cargoes and mouse $\beta$-cell proliferation $(8,11,14,15)$.

The SG luminal, $N$-glycosylated juxtamembrane region of ICA512 TMF comprises the membrane-proximal ectodomain (ICA512 MPE). X-ray crystallography revealed that ICA512 MPE is a SEA (Sea urchin sperm protein, Enterokinase, Agrin) domain, which is compatible with its potential involvement in cell adhesion and the formation of homo- and heterodimers $(16-19)$. Further studies indicated that $\beta$-strands in ICA512 MPE promote pro-ICA512 dimerization and regulate it from the endoplasmic reticulum (20). A similar SEA domain is also found in the corresponding region of phogrin $(21,22)$.

ICA512 NTF, the other luminal segment resulting from the proprotein convertase processing of ICA512, is much less characterized. The ICA512 NTF region encompassing residues 35-131, immediately after the signal peptide, exhibits sequence similarity to the regulated endocrine-specific protein 18
(Resp18; Fig. 1). As ICA512 and phogrin, Resp18 is widely expressed in peptide hormone-secreting endocrine cells, including $\alpha$-, $\beta$-, and $\delta$-cells of the pancreatic islets, and its expression is up-regulated in conditions stimulating SG biogenesis (23).

In view of its similarity to Resp18, the segment corresponding to residues 35-131 of ICA512 was named Resp18 homology domain (RESP18HD) (24). Interestingly, ICA512 RESP18HD has a conserved cysteine-rich $\mathrm{N}$-terminal region (residues 35-62), which is absent in Resp18 (Fig. 1B).

In previous studies, we showed that ICA512 RESP18HD contains sufficient information to direct green fluorescent protein (GFP) to insulin SGs, whereas deletion of the entire ICA512 NTF, which includes ICA512 RESP18HD, causes the constitutive delivery of ICA512 to the plasma membrane, hence abolishing SG targeting $(20,24)$.

Although the detailed mechanism of proprotein sorting into SGs is not well-established, it is clear that signal-mediated sorting and congregation-aggregation of regulated cargoes contribute to the biogenesis of SGs (25-28).

Congregation-aggregation processes are of two main classes: liquid-liquid phase transitions (LLPT) and liquid-solid phase separation or, for short, aggregation. LLPT and aggregation have in common a stage of segregation in which the participant molecules congregate guided by multiple noncovalent interactions. However, the outcomes of these two processes are different, being either separated liquid-like or solid-like phases. These two kinds of phases establish a dynamic exchange with a main liquid phase in which macromolecules form a nonhomogeneous solution.

Liquid-like phases have surface and bulk properties typical of liquids and acquire droplet morphology (29). Typical examples are the nucleolus, Cajal bodies, nuclear speckles, stress granules, P-bodies, and germ granules (30). Solid-like phases result from protein aggregation that causes microscopic solid deposition.

The morphology of solid deposits is exuberant. Crystal-like deposits are formed in endocrine and exocrine SGs $(26,28)$. Amyloids are ordered fibrillar protein deposits formed in neurodegenerative diseases, such as Alzheimer's, Parkinson's, Huntington's, amyotrophic lateral sclerosis (ALS), CreutzfeldtJakob diseases, and type 2 diabetes (29-34) In the latter, islet amyloid polypeptide produced by pancreatic $\beta$-cells accumulates in the islets, leading to cell dysfunction, death, and insulin deficiency. In contrast, typical amorphous aggregates in the eye lens cause cataracts, a widespread disease of aging.

Protein congregation involves heterotropic and nonstoichiometric protein-protein interactions, and it is characterized by its collective and cooperative nature. Also, it implies robust recognition mechanisms, acting simultaneously upon very different proteins. In this regard, it is revealing that proteins prone to congregation are frequently rich in intrinsically disordered regions (IDRs) and low complexity regions, as if well-folded proteins were less susceptible to it. Partially unfolded protein conformations are ideal candidates for the promotion of collective congregation because they expose a higher proportion of active areas compared with native states, thus facilitating intermolecular over intramolecular interactions. 


\section{ICA512 RESP18HD condensing and anti-amyloidogenic activity}

Given that cross-reactivity is an essential aspect of protein congregation, the identification and characterization of proteins that participate in congregations, and particularly of those that may display a congregating activity, promise to be of singular importance to boost our understanding of cellular processes, both in normal and pathological conditions. In this present study, we investigate in greater detail the biochemical and biophysical properties of ICA512 RESP18HD in relation to its congregating activity.

\section{Results}

\section{ICA512 RESP18HD aggregates and binds $\mathrm{Zn}^{2+}$}

The auto-aggregating activity of ICA512 RESP18HD, demonstrated by light-scattering measurements (Fig. $2 A$ ), was negligible at $\mathrm{pH} 4.5$, very slow at $\mathrm{pH} 6.8$, and increased abruptly above $\mathrm{pH}$ 7.0.

This $\mathrm{pH}$ dependence suggested that ICA512 RESP18HD histidine residues (His-38, His-49, and/or His-98) might be involved in the aggregation. Therefore, we tested possible histidine ligands. Micromolar concentrations of $\mathrm{Zn}^{2+}$ abolished aggregation, and the effect was reversible by equimolar EDTA (Fig. $2 B$ ). Neither $\mathrm{Ca}^{2+}$ nor $\mathrm{Mg}^{2+}$ acted like $\mathrm{Zn}^{2+}$; however, $\mathrm{Cu}^{2+}$ mimicked $\mathrm{Zn}^{2+}$ but with lower efficiency (Fig. S1A).

Complete inhibition of ICA512 RESP18HD self-aggregation

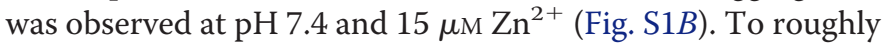
estimate ICA512 RESP18HD affinity for $\mathrm{Zn}^{2+}$, the aggregation kinetics was modeled as a first-order reaction, and an exponential decay was fit to the calculated rate constants (Fig. S1C). This simplified treatment allowed $\mathrm{Zn}^{2+} \mathrm{IC}_{50}$ to be estimated as $2 \mu \mathrm{M}$.

Direct equilibrium measurements of $\mathrm{Zn}^{2+}$ binding at $\mathrm{pH} 7.4$ were complicated by aggregation. However, aggregation was minimal at $\mathrm{pH} 4.5$, and microfiltration through $3-\mathrm{kDa}$ membranes could be performed (data not shown), and by using the law of mass action, a dissociation constant of $1 \mu \mathrm{M}$ was calculated. This result suggests that ICA512 RESP18HD binds $\mathrm{Zn}^{2+}$ even in the acidic conditions of $\mathrm{pH} 5.5$ present in the lumen of newly generated SGs (35), in which the concentration of $\mathrm{Zn}^{2+}$ is $\approx 20 \mathrm{~mm}$ (36).

Far-UV CD spectra of ICA512 RESP18HD are shown in Fig. $\mathrm{S} 1 D$. The spectrum at $\mathrm{pH} 4.5$ corresponded to that of a largely unstructured peptide, and addition of $50 \mu \mathrm{M} \mathrm{Zn}{ }^{2+}$ did not change it significantly. Both of these conditions inhibited the aggregation of ICA512 RESP18HD.

Instead, at $\mathrm{pH} 7.4$ and in the presence of $50 \mu \mathrm{M} \mathrm{Zn}{ }^{2+}$, a condition that also inhibits ICA512 RESP18HD aggregation, the CD spectrum evidenced two negative bands at 205 and 218 $\mathrm{nm}$ and one positive band at $190 \mathrm{~nm}$ suggestive of $\alpha$-helix for-

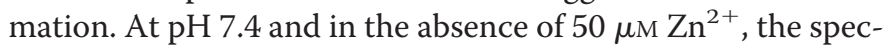
trum taken at the onset of aggregation evidenced the same secondary structure signature. Based on these results, we hypothesize that fully unfolded ICA512 RESP18HD has little tendency to aggregate and that partial folding is required to achieve an aggregation-prone state.

To better delineate the ICA512 RESP18HD residues involved in the aggregation reaction, the variant 35-90 (RESP18HD90) was prepared. This variant contains the $\mathrm{N}$-terminal Cys-rich motif (residues 35-61) but lacks the IDR encompassing resi- dues 91-131 (see below). ICA512 RESP18HD90 did not aggregate under any of the conditions tested above (data not shown).

\section{ICA512 RESP18HD-insulin aggregation}

Unless otherwise indicated, the results reported in this section are from experiments conducted in incubation media containing $2 \mu \mathrm{M}$ ICA512 RESP18HD and $8 \mu \mathrm{M}$ insulin.

At $\mathrm{pH}$ 6.8, neither insulin nor ICA512 RESP18HD formed higher-order aggregates in isolation. However, when incubated together, ICA512 RESP18HD and insulin formed aggregates, readily detectable by light scattering (Fig. 2C). ICA512 RESP18HD90 did not aggregate with insulin (data not shown) and neither ICA512 RESP18HD nor insulin aggregated at $\mathrm{pH}$ 4.5 (Fig. 2D).

$\mathrm{Zn}^{2+}$ inhibited the self-aggregation of ICA512 RESP18HD at $\mathrm{pH}$ 7.4 (Fig. 2B), but it did not inhibit the coaggregation of insulin and ICA512 RESP18HD at pH 6.8 (Fig. 2E). Thus, the aggregation of ICA512 RESP18HD with insulin is not a consequence of previous aggregation of ICA512 RESP18HD. Because $\mathrm{Ca}^{2+}$ is present at high concentrations in the SGs, its effects in the aggregation reactions was also investigated. $\mathrm{Ca}^{2+}$ did not inhibit the self-aggregation of ICA512 RESP18HD at $\mathrm{pH}$ 7.4 (Fig. S1A) or the coaggregation of insulin and ICA512 RESP18HD at pH 6.8 (Fig. 2E).

To investigate whether the observed aggregation of ICA512 RESP18HD with insulin at $\mathrm{pH} 6.8$ could result from ICA512 RESP18HD removal of $\mathrm{Zn}^{2+}$ from insulin, it was verified that EDTA did not induce insulin aggregation (Fig. 2C).

Aggregates formed by coincubation of ICA512 RESP18HD and insulin at pH 6.8 dissolved at pH 4.0 (Fig. 2F). Moreover, aggregation was not influenced by reducing agents like DTT, phosphine, or mercaptoethanol (data not shown), suggesting that thiol-disulfide exchange reactions were not involved in the process.

ICA512 RESP18HD-insulin aggregation at pH 6.8 was completely blocked by preincubation with $100 \mathrm{~mm} \mathrm{~L}$-arginine (data not shown). L-Arginine is an unspecific anti-aggregating agent employed in protein folding protocols (37). L-Arginine added when aggregation was in progress prevented further aggregation, but already formed aggregates did not dissolve.

ICA512 RESP18HD was also assayed for aggregation at $\mathrm{pH}$ 6.8 in the presence of proinsulin $\left(\mathrm{His}_{6}\right.$ ) and amylin. Proinsulin behaved similarly to insulin (data not shown). Amylin was negative in the reaction with ICA512 RESP18HD but acted as a potent inhibitor in the aggregation of the pair ICA512 RESP18HD-insulin (Fig. 2G). This activity of amylin suggests that it interacts with either ICA512 RESP18HD, insulin, or with their complex blocking aggregation. Interestingly, an insulin anti-aggregating activity of amylin has been reported before (38).

In SGs, insulin is present mostly as a crystalline condensate and at concentrations as high as $30 \mathrm{~mm}$ (39). The concentration of soluble insulin potentially able to coaggregate with ICA512 RESP18HD is not known, but it could be higher than that assayed in the above experiments $(8 \mu \mathrm{M})$. Therefore, the aggregation reaction was also tested at $2 \mu \mathrm{M}$ ICA512 RESP18HD and $400 \mu \mathrm{M}$ insulin. Aggregation was strongly inhibited under this condition (data not shown). 

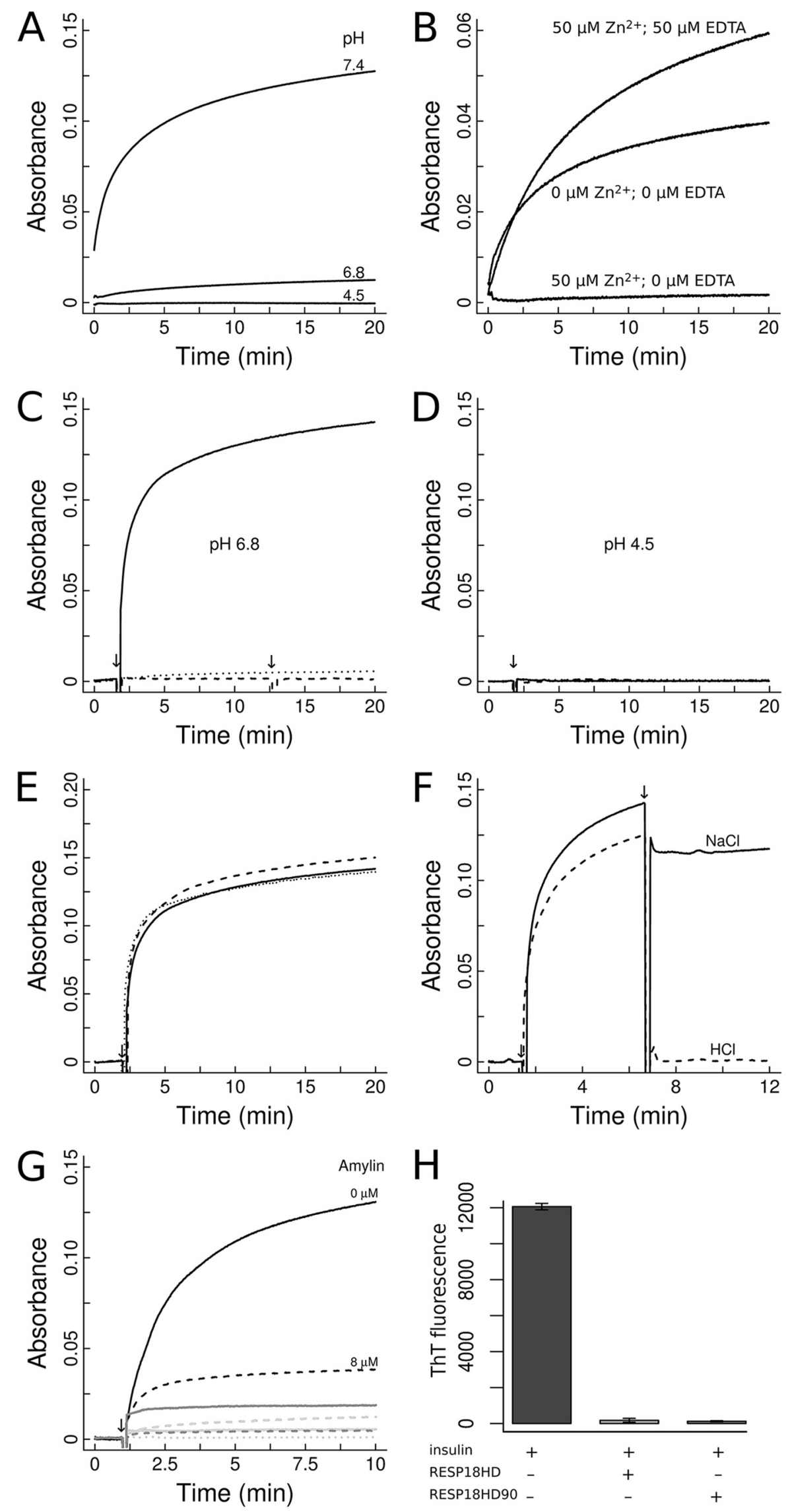


\section{ICA512 RESP18HD condensing and anti-amyloidogenic activity}
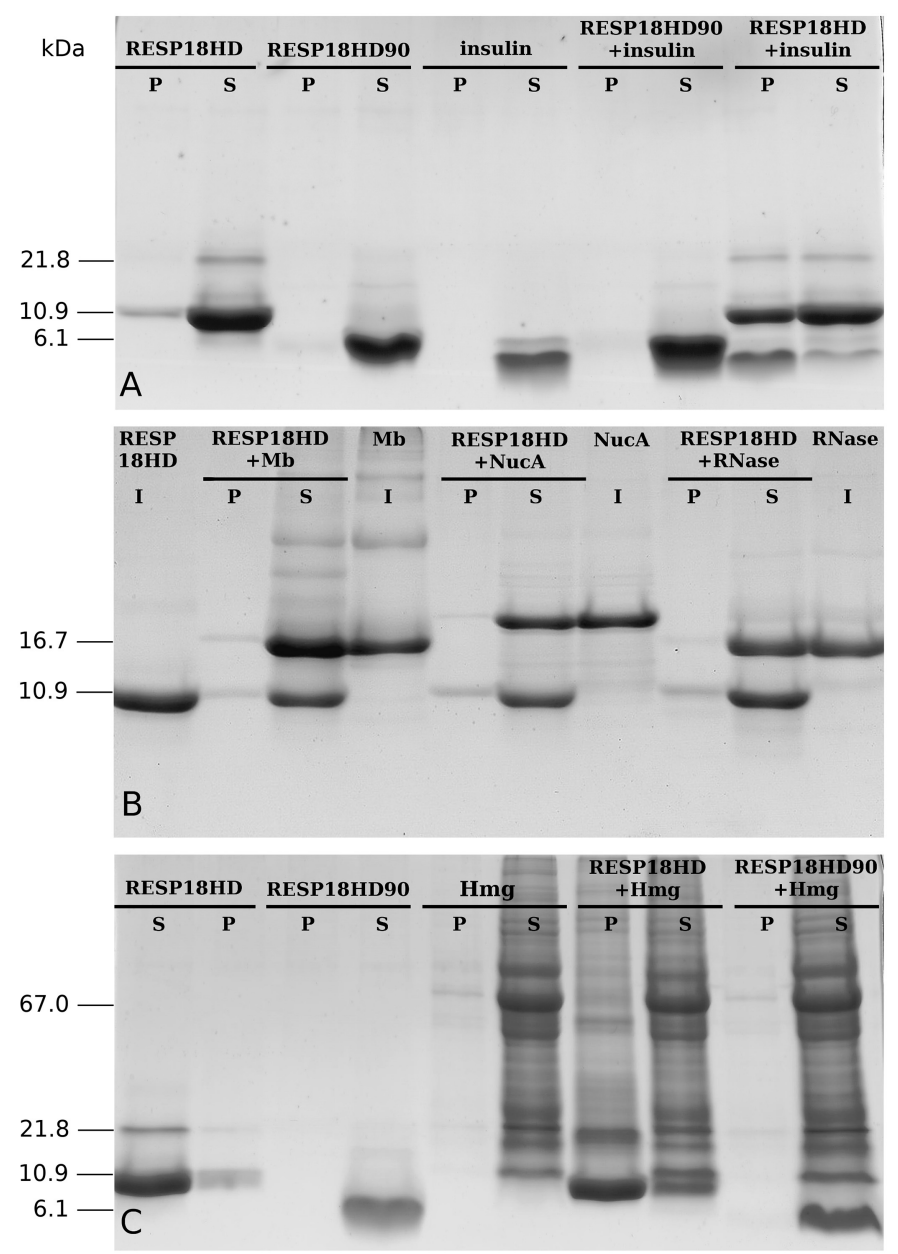

Figure 3. Isolation of ICA512 RESP18HD aggregates. The aggregation reaction was conducted as described in Fig. 2. Pellets $(P)$ and supernatants $(S)$ obtained by centrifugation from the sample incubates were loaded quantitatively into the SDS-PAGE lanes. A, co-incubation of insulin $(8 \mu \mathrm{M})$ and ICA512 RESP18HD $(2 \mu \mathrm{M})$ results in a pellet containing both proteins. ICA512 RESP18HD90 does not coaggregate with insulin, and therefore both proteins are recovered only in the supernatant. Control lanes indicate that none of the proteins aggregate in isolation. $B$, ICA512 RESP18HD (2 $\mu \mathrm{M})$ does not coaggregate with myoglobin, staphylococcal nuclease, or RNase A ( $8 \mu \mathrm{m})$. These well-characterized, soluble proteins, along with ICA512 RESP18HD, are recovered in the soluble fractions $(S)$. Centrifugation was omitted in control incubates (I). C, ICA512 RESP18HD ( $2 \mu \mathrm{M})$ exhibits a broad coaggregating activity upon a pancreas homogenate (Hmg). ICA512 RESP18HD90 lacks such activity.

The aggregate and soluble fractions from ICA512 RESP18HDinsulin incubates could be easily separated by centrifugation at $13,000 \mathrm{rpm}$. The recovery of significant amounts of both proteins in the pellet demonstrated that ICA512 RESP18HD and insulin coaggregate when incubated together at $\mathrm{pH} 6.8$
(Fig. 3A). In contrast, ICA512 RESP18HD90 did not coaggregate with insulin, as both proteins were not recovered together in the pellet (Fig. $3 A$ ).

Separation of pellets and supernatants followed by SDSPAGE and band quantification established the proportion of each protein in the aggregate for different concentration ratios of ICA512 RESP18HD/insulin in the incubation media (Figs. S2 and S3 and Methods S1). In excess of insulin, as likely occurs in cells, coincubation produced an aggregate with $2.8 \mathrm{~mol}$ of insulin/mol of ICA512 RESP18HD. In excess of ICA512 RESP18HD, the proportion was $0.4 \mathrm{~mol}$ of insulin/mol of ICA512 RESP18HD.

The variable proportion of each component suggests that the aggregate is formed by a solid-phase condensation mechanism, influenced by the relative concentrations of the interacting particles, which is different from specific mechanisms of aggregation involving constant stoichiometric relationships.

The effect of $\mathrm{Zn}^{2+}$ on the coaggregation reaction was further assessed by centrifugation and SDS-PAGE analysis (Fig. S4). This analysis indicated that at low concentrations $\mathrm{Zn}^{2+}$ does not inhibit the coaggregation, corroborating the above results obtained by light-scattering measurements (Fig. 2E). However, $100 \mu \mathrm{M} \mathrm{Zn}^{2+}$ had a moderate inhibitory effect on the incorporation of ICA512 RESP18HD in the coaggregate.

\section{Temperature dependence of the aggregation}

ICA512 RESP18HD self-aggregation and ICA512 RESP18HDinsulin coaggregation were tested at different temperatures in the $5-40{ }^{\circ} \mathrm{C}$ range. Aggregation velocities increased smoothly with temperature (data not shown), as expected for typical collisional mechanisms. In a typical LLPT, for a given protein concentration, there is a critical temperature above which a single homogeneous phase exists (40). Such critical temperatures could not be detected at the protein concentrations assayed in this work. The absence of a temperature-dependent cutoff in the aggregation reactions of ICA512 RESP18HD is compatible with solid-liquid phase separations, as those that result in microscopic deposits of amorphous aggregates or the formation of amyloid fibers.

Thioflavin $\mathrm{T}$ (ThT) is a highly-specific probe for protein fibrillation because its fluorescence increases several orders of magnitude upon binding to the cross- $\beta$-structure of amyloid fibrils. ICA512 RESP18HD self-aggregates and ICA512 RESP18HD-insulin coaggregates formed at $20^{\circ} \mathrm{C}$ tested negative in a ThT fluorescence assay for cross- $\beta$-fibrils (data not

Figure 2. Time-course aggregation of ICA512 RESP18HD. The reaction was monitored by the increment of absorbance (light scattering) at $400 \mathrm{~nm}$. $A$ and $B$, reaction was initiated by adding ICA512RESP $18 \mathrm{HD}$ to the reaction buffer at $2 \mu \mathrm{m}$ final concentration. $C-G$, reaction was initiated by adding insulin 8 to $2 \mu \mathrm{M}$ to ICA512 RESP18HD solutions. Arrows mark the time of reagent addition. A, ICA512 RESP18HD aggregation is negligible at pH 4.5, barely detectable at pH 6.8, and very rapid at $\mathrm{pH} 7.4 . \mathrm{B}, \mathrm{Zn}^{2+}$ inhibits aggregation of ICA512 RESP18HD at $\mathrm{pH} 7.4$, an effect that is reversed by equimolar EDTA. C, incubation of ICA512 RESP18HD and insulin at pH 6.8 (solid line) results in aggregation. Insulin (dashed line) or ICA512 RESP18HD (dotted line) alone do not aggregate separately. The 2nd arrow in the insulin trace marks the addition of $12.5 \mu \mathrm{M} \mathrm{EDTA}$. D, neither insulin alone (dashes), ICA512 RESP18HD alone (dots), nor in combination (solid line) aggregate at $\mathrm{pH} 4.5$. E, aggregation reaction of insulin and ICA512 RESP18HD at pH 6.8 (solid line) is unaffected by $50 \mu \mathrm{M} \mathrm{Zn^{2+ }}$ (dashed line) or $50 \mu \mathrm{M} \mathrm{Ca}{ }^{2+}$ (dotted line). $F$, aggregation at $\mathrm{pH} 6.8$ is reversed by acidification to $\mathrm{pH} 4.0$ with $\mathrm{HCl}$ (dashed line; arrow at $400 \mathrm{~s}$ ). Adding equivalent concentrations of $\mathrm{NaCl}$ instead of $\mathrm{HCl}$ stops further aggregation but does not dissolve preexistent aggregates (solid line). G, amylin inhibits ICA512 RESP18HD-insulin aggregation. The reaction was performed in the absence of amylin (solid black line) and with $8 \mu \mathrm{m}$ amylin (dashed black line). ICA512 RESP18HD is required for aggregation because neither $8 \mu \mathrm{m}$ insulin $+8 \mu \mathrm{m}$ amylin (solid gray line), $2 \mu \mathrm{M}$ ICA512 RESP18HD $+8 \mu \mathrm{m}$ amylin (dashed gray line), $8 \mu \mathrm{m}$ amylin (solid light gray line), $2 \mu \mathrm{M}$ ICA512 RESP18HD (dashed light gray line), nor $8 \mu \mathrm{m}$ insulin (dotted light gray line) aggregate in the assay. $H$, ThT fluorescence assay for insulin fibrillation. Fibrillation was performed at $60^{\circ} \mathrm{C}$ with stirring (see "Experimental procedures"). The composition of the sample incubates is indicated at the bottom. Error bars indicate the standard deviation of three independent experiments. 


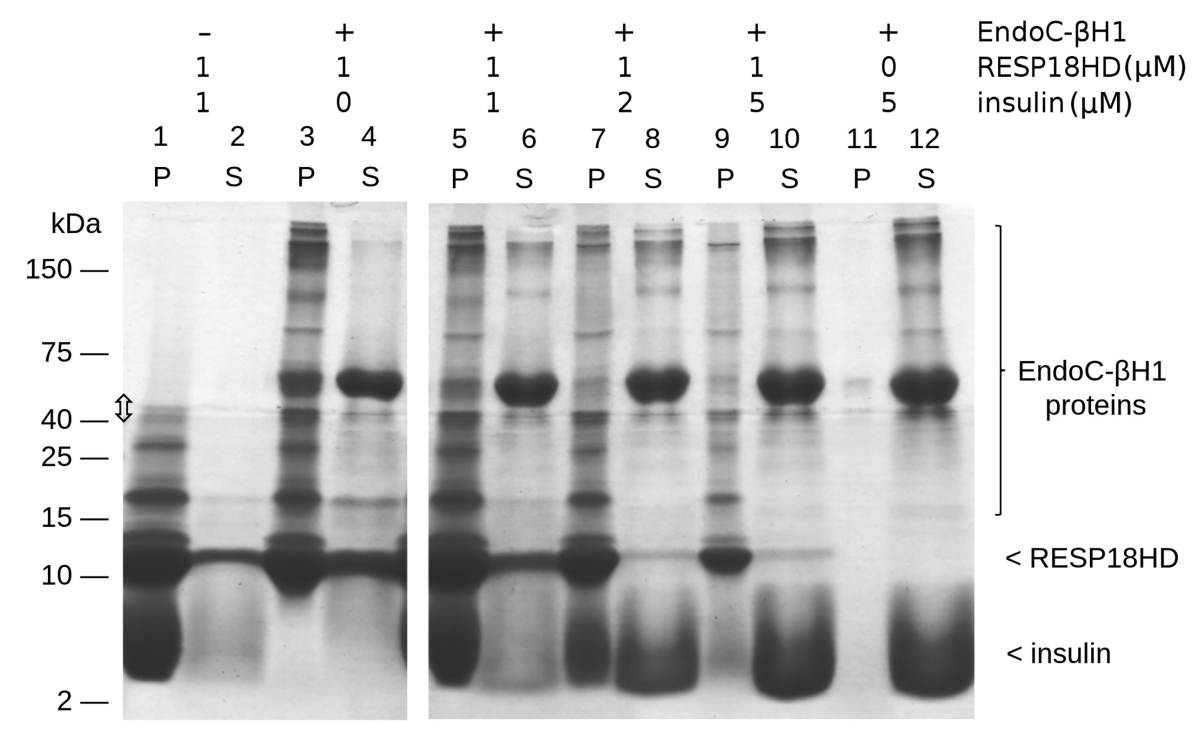

Figure 4. Coaggregation reaction of ICA512 RESP18HD and human EndoC- $\boldsymbol{\beta}$ H1 cell proteins. Two-layer SDS-PAGE separating gels were used in the analysis (10 and $17 \%$ acrylamide, top and bottom, respectively). The boundary between the layers is marked with a double-headed arrow. Fixed amounts of EndoC $-\beta \mathrm{H} 1$ homogenate were incubated with the indicated concentrations of ICA512 RESP18HD and insulin. The incubation mixture was processed as described in Fig. 3 to separate pellet $(P)$ and soluble $(S)$ fractions. Lanes 1 and 2, incubation of equimolar concentrations of insulin and ICA512 RESP18HD in the absence of EndoC $-\beta \mathrm{H} 1$ proteins results in coaggregation and recovery of most of both proteins in the pellet. Slow formation of covalently-linked multimers occurs spontaneously in ICA512 RESP18HD solutions (24). Here, however, this tendency was exacerbated by the coincubation with insulin. Lanes 3 and 4, ICA512 RESP18HD coaggregates with EndoC $-\beta \mathrm{H} 1$ proteins in the absence of added insulin. Lanes 5-10, ICA512 RESP18HD coaggregates with added insulin and EndoC- $\beta$ H1 proteins. However, a 5-fold excess of insulin over ICA512 RESP18HD decreases the yield of insulin in the coaggregate. Lanes 11 and 12 , insulin per se has no aggregating activity on the protein homogenate.

shown), corroborating that the solid deposits were of amorphous nature.

\section{Inhibition of insulin fibrillation}

Insulin submitted to high temperatures, stirring, or agitation converts into amyloid cross- $\beta$-fibrils (41). To test the possibility that ICA512 RESP18HD could affect the fibrillation of insulin, a fibrillation assay was set up in which insulin solutions were subjected to physical stress by incubation at $60{ }^{\circ} \mathrm{C}$ under stirring.

As expected, stressed insulin solutions yielded a strong ThT fluorescent signal. In the presence of either ICA512 RESP18HD or ICA512 RESP18HD90, ThT fluorescence was negligible, indicating that insulin fibrillation was abolished (Fig. 2H). Neither of the two ICA512 RESP18HD variants fibrillated on their own account (data not shown). These results imply that residues 35-90 of ICA512 RESP18HD bind to insulin and impede its fibrillation.

\section{ICA512 RESP18HD possesses broad protein-condensing activity}

To evaluate the specificity of the reaction, several pure, wellcharacterized, and highly-soluble proteins were incubated with ICA512 RESP18HD under conditions similar to those used in the aggregation tests with insulin, and the pellets obtained by centrifugation were analyzed by SDS-PAGE. The results for myoglobin, staphylococcal nuclease, and RNase are shown in Fig. 3B. Similar results were obtained with lysozyme and human serum albumin (data not shown). Altogether, these results indicate that ICA512 RESP18HD has no condensing activity toward these isolated highly-soluble proteins.

Next, we asked whether the condensing activity of ICA512 RESP18HD was preferentially directed to particular proteins in a complex mixture. To that end, the reaction was set up as above but replacing pure proteins by cell homogenates. The result with a rat pancreas homogenate is shown in Fig. $3 C$. In the absence of ICA512 RESP18HD, few proteins and in trace amounts were recovered in the pellet (Fig. 3C, 5th lane). Adding ICA512 RESP18HD to the incubation mixture had a large effect on the reaction; nearly all proteins in the homogenate appeared with substantial yield in the pellet (compare 7th and 8th lanes with 5th and 6th lanes in Fig. 3C). Interestingly, ICA512 RESP18HD90 did not aggregate proteins from the pancreas homogenate (Fig. 3C, 9th and 10th lanes). Because ICA512 RESP18HD90 did not aggregate insulin (Fig. 3A), it can be inferred that the aggregating activity of ICA512 RESP18HD requires residues $91-131$.

A density image analysis of the homogenate coprecipitation illustrates further the remarkable condensing activity of ICA512 RESP18HD (Fig. S5); in most cases, at least half of each protein band was recovered in the pellet fraction, as well as nearly all ICA512 RESP18HD.

Interestingly, pure insulin added to the lysate was recovered in the pellet with low yield (Fig. S5). Thus, the affinity of ICA512 RESP18HD for insulin was counterbalanced by the competition for homogenate proteins that were in huge excess. Similar results were obtained with Saccharomyces cerevisiae and liver homogenates (data not shown).

Human EndoC- $\beta \mathrm{H} 1$ cells constitute an excellent experimental model to study insulin secretion (42). Therefore, the coaggregating activity of ICA512 RESP18HD was assayed with homogenates of these cells, and the results are shown in Fig. 4. ICA512 RESP18HD broadly coaggregated with EndoC $-\beta \mathrm{H} 1$ cell proteins (Fig. 4, lanes 3 and 4), similarly to what was described above with other cell homogenates. Insulin per se did 


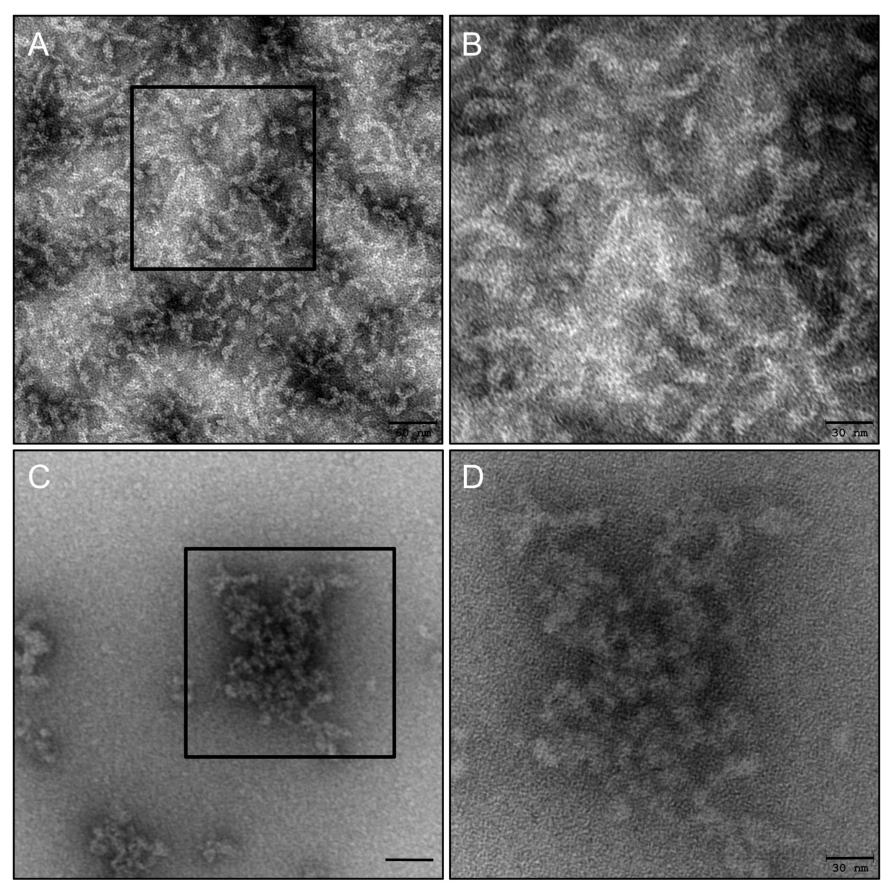

Figure 5. TEM of ICA512 RESP18HD and ICA512 RESP18HD-insulin aggregates. The aggregate of ICA512 RESP18HD and the coaggregate of ICA512 RESP18HD and insulin at $\mathrm{pH} 6.8$ were prepared for negative staining. $A$, overview of ICA512 RESP18HD aggregates alone with higher magnification of the enclosed areas in B. C and D, low- and high-magnification images for ICA512 RESP18HD together with insulin. In both cases, the aggregate is of an amorphous nature and lacks periodic fibrils. The sponge-like matrix formed is thinner and more porous in the ICA512 RESP18HD alone aggregation. Scale bars, $A$ and $C, 60 \mathrm{~nm} ; B$ and $D, 30 \mathrm{~nm}$.

not coaggregate proteins in EndoC- $\beta \mathrm{H} 1$ cell homogenates (Fig. 4, 11th and 12th lanes). When in combination, ICA512 RESP18HD and insulin coaggregated along with the homogenate (Fig. 4, 5th and 10th lanes). However, the yield of insulin in the coaggregate varied, with most insulin being recovered in the supernatant, as also observed with rat pancreas homogenates (Fig. S5).

\section{ICA512 RESP18HD-insulin condensates characterized by TEM}

TEM analysis confirmed the amorphous nature of both ICA512 RESP18HD and ICA512 RESP18HD-insulin aggregates and the lack of fibers and regularly packed particles (Fig. 5 ). This result is coherent with the lack of fixed stoichiometry in the formation of the segregated solid phase described above. ICA512 RESP18HD-insulin preparations showed denser aggregates than in the case of samples containing ICA512 RESP18HD alone.

\section{Residues 91-131 of ICA512 RESP18HD constitute an IDR}

As mentioned above, ICA512 RESP18HD90 was unable to coaggregate with insulin or with other proteins in pancreas homogenates. Therefore, it was inferred that the condensing activity of ICA512 RESP18HD requires residues 91-131. Using the sequence-based disorder prediction servers, PONDR VSL2 (http://www.pondr.com $/^{5}$ (43)), IUPRED, and ANCHOR (http://iupred2a.elte.hu/ ${ }^{5}$ (44)), residues $91-131$ of ICA512

${ }^{5}$ Please note that the JBC is not responsible for the long-term archiving and maintenance of this site or any other third party hosted site.
RESP18HD were identified as an IDR. This sequence region is enriched in arginine and proline residues (Fig. 1B), a typical signature of structural disorder.

Interestingly, the IDR segment of ICA512 RESP18HD is part of the larger predicted IDR regions within ICA512 NTF (residues 109-176, 283-341, and 370-465; Fig. 1A), which open the possibility that most of ICA512 NTF could be involved in condensing processes.

\section{ICA512 RESP18HD antibody staining in cells and islets}

We reported previously that the C-terminally GFP-tagged ICA512 RESP18HD (residues 1-131) is targeted to insulin SGs, showing that ICA512 N-terminal domain contains sufficient information for SG localization in $\beta$-cell like INS-1 cells (20). For the current analyses, we transfected INS-1 cells with new constructs in which the GFP tag was replaced by its derivative Turquoise 2 (TQ2), TQ2 behaves essentially as GFP but is $\mathrm{pH}$ insensitive and less prone to aggregation.

Also for these analyses, we generated a novel mouse monoclonal ICA512 RESP18HD antibody. Because ICA512 RESP18HD shares sequence homology with phogrin and Resp18 (Fig. 1B), we verified the specificity of this new antibody. To this end, INS-1 cells were transfected with human ICA512 RESP18HDTQ2 (residues 1-131), Phogrin RESP18HD-TQ2 (residues 1-136), or Resp18-TQ2 (Resp18 residues 1-228) fusion proteins. INS-1 cells expressing the constructs were analyzed by immunoblotting, with either mouse anti-GFP (for the TQ2 tag) or the novel anti-ICA512 RESP18HD antibodies (Fig. 6A).

As expected, ICA512 RESP18HD-TQ2 was detected with both the anti-GFP and the anti-ICA512 RESP18HD antibodies, mainly as the intact fusion protein of $\approx 40 \mathrm{kDa}$ (Fig. $6 \mathrm{~A}$, $1 \mathrm{st}$ lane). Phogrin RESP18HD-TQ2 and Resp18-TQ2 were also recognized, mainly as intact fusions, by the anti-GFP antibody but not by the anti-ICA512-RESP18HD antibody (Fig. 6A, 2nd and 3rd lanes), demonstrating the specificity of the latter for ICA512. Further immunoblotting analysis using C-terminal deletion and site-specific mutants established that the novel antibody recognizes a C-terminal epitope encompassing residue 125 of ICA512 RESP18HD (Fig. S6).

Next, the anti-ICA512 RESP18HD antibody was tested for detection of endogenous RESP18HD in human pancreatic tissue sections and human EndoC- $\beta \mathrm{H} 1$ cells by immunofluorescence microscopy. The anti-ICA512 RESP18HD antibody signal was enriched in the endocrine cells and islets, where it overlapped with the signal for insulin (Fig. 6B). As expected, in EndoC $-\beta \mathrm{H} 1$ cells, the immunofluorescence signal for ICA512 RESP18HD colocalized with the punctated insulin-positive structures (Fig. 6C). Finally, the specificity of the anti-ICA512 RESP18HD antibody was further corroborated by immunoblotting of human EndoC- $\beta \mathrm{H} 1$ cell lysates depleted of ICA512 by RNAi (Fig. S7).

\section{ICA512 RESP18HD is processed upon regulated secretion}

Next, we exploited the novel anti-ICA512 RESP18HD antibody to investigate the processing and putative secretion of ICA512 RESP18HD and variants thereof. To this aim, WT and ICA512 RESP18HD-TQ2-transfected INS-1 cells were cultured in resting or glucose-stimulated conditions, and the cell 
A

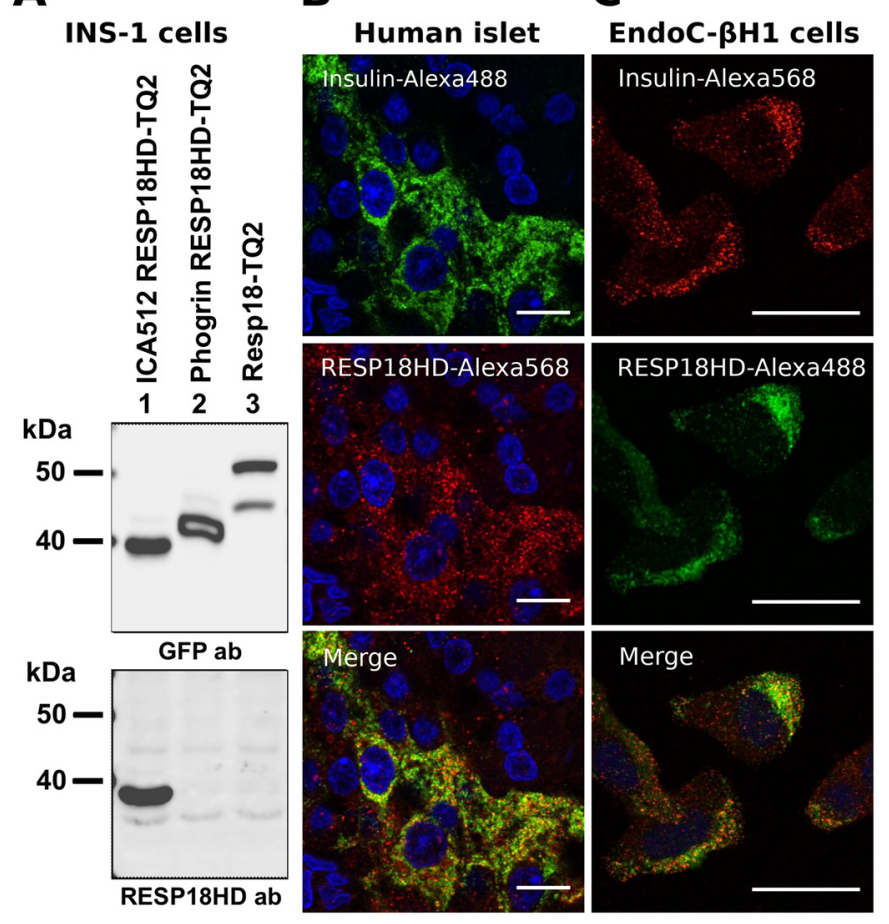

Figure 6. Immunostaining with the anti-ICA512 RESP18HD antibody. $A$, rat INS-1 cells transfected with constructs expressing C-terminal TQ2 fusion proteins of human ICA512 RESP18HD (residues 1-131), phogrin RESP18HD (residues 1-136), or Resp18 (residues 1-228) cells were lysed and analyzed by SDS-PAGE and immunoblotting, using for detection either mouse anti-GFP (that cross-reacts with TQ2) or mouse anti-ICA512 RESP18HD antibodies. All intact TQ2 fusion proteins were detected by the mouse anti-GFP antibody, whereas the mouse anti-ICA512 RESP18HD antibody only recognized ICA512 RESP18HD-TQ2. B, immunostaining of human pancreatic tissue sections. $C$, human EndoC $-\beta \mathrm{H} 1$ cells with guinea pig anti-insulin and mouse anti-ICA512 RESP18HD antibodies. Insulin and ICA512 RESP18HD signals were found restricted to the islets with a punctated signal consistent with SGs labeling ( $B$ and C). Scale bars, $20 \mu \mathrm{m}$; $a b$, antibody.

lysates and the immunoprecipitates from the corresponding culture media were subjected to immunoblotting analysis (Fig. 7, $A$ and $B$, respectively).

In resting and stimulated INS-1 cells, full-length "mature" ICA512 RESP18HD-TQ2 was detected by anti-GFP and antiICA512 RESP18HD antibodies as a band of $\approx 40 \mathrm{kDa}$ (Fig. $7 A$, asterisks). In resting cells, the anti-GFP antibody detected also a faint band $>40 \mathrm{kDa}$, indicating the presence of pro-ICA512 RESP18HD-TQ2 species, which conceivably still contained the signal peptide. Mature ICA512 RESP18HD-TQ2 detected with both antibodies was more abundant in resting than in stimulated cells, which is compatible with its secretion upon glucose stimulation.

In resting, but not in stimulated, cells the anti-GFP antibody recognized an ICA512 RESP18HD-TQ2 proteolytic fragment of $\approx 30 \mathrm{kDa}$ (Fig. $7 A$, arrowhead). This fragment corresponds to TQ2 preceded by a short sequence from the $C$ terminus of ICA512-RESP18HD. Its absence in stimulated cells suggests that it may be exported along with the mature form upon stimulation.

Another proteolytic fragment of $\approx 27 \mathrm{kDa}$ compatible with the bare size of TQ2 was detected in resting and stimulated cells (Fig. 7A, double arrowheads). The fact that this fragment was not depleted in stimulated cells is an indication that it may be not secreted, as often observed for cytosolic GFP/TQ2 remaining after incomplete proteasomal degradation of fusion proteins (Ref. 45 and references therein).

Remarkably, in the culture media, the $40-\mathrm{kDa}$ mature ICA512 RESP18HD-TQ2 was present in significant amounts only with stimulated cells (Fig. $7 B$, asterisks), which were also enriched for the presence of a single $\approx 30-\mathrm{kDa}$ fragment (Fig. $7 B$, arrowhead). The abundant recovery of both ICA512 RESP18HD-TQ2 species in the culture media of glucose-stimulated cells suggests that the $40-\mathrm{kDa}$ fragment is secreted in a regulated fashion and converted to the $30-\mathrm{kDa}$ species by proteolysis.

\section{ICA512 RESP18HD-processing site}

Immunoprecipitates from culture media of glucose-stimulated INS-1 cells expressing ICA512 RESP18HD-TQ2 were run on SDS-PAGE, and the isolated $\approx 30-\mathrm{kDa}$ band was subjected to "in gel" digestion with trypsin and MS analysis.

Observed peptide masses and fragmentation patterns (data not shown) identified ( $a$ ) several peptides corresponding to the inner sequence of TQ2 and (b) two N-terminally extended peptides with the sequence "DRSGLAPGPVATMVS" and "SGLAPGPVATMVSK," respectively. In these two peptides, "DRSGLAP" and "SGLAP" map to the C terminus of ICA512 RESP18HD (see also Fig. 1B; residues 125-131, and 127-131, respectively); "GPVAT" corresponds to a linker sequence between ICA512 RESP18HD and TQ2, and "MVSK" is from the $\mathrm{N}$ terminus of TQ2. The shorter peptide is likely the result of the trypsin digestion applied. Because the single $\approx 30-\mathrm{kDa}$ fragment reacted with the anti-ICA512 RESP18HD antibody (Fig. $7 A$, arrowhead), which detects an epitope, including residue 125 (see also Fig. S6), it is concluded that the processing site locates close to residue 125 (see Fig. $1 B$ ) and within the IDR of ICA512 RESP18HD. Because of limitations of the ICA512 RESP18HD antibody, epitope recognition and also other potential peptide recognition by the MS analysis, we cannot completely exclude the presence of other proteolytic sites beyond Asp-125.

\section{Discussion}

Our finding that ICA512 RESP18HD possesses in vitro protein-condensing activity turns it into a potentially important factor for $\mathrm{SG}$ biogenesis and regulated secretion. In this regard, ICA512 RESP18HD resembles other luminal domains of SG membrane proteins, including dopamine $\beta$-hydroxylase, peptidyl glycine $\alpha$-amidating enzyme, carboxypeptidase E, and granin, which have been reported to coaggregate with SG cargoes proteins (Ref. 46 and references therein). Interestingly, these condensing factors aggregate at the acidic $\mathrm{pH}$ of mature SGs, whereas ICA512 RESP18HD displays condensing activity at $\mathrm{pH}$ close to neutral, with acidic $\mathrm{pH}$ inhibiting its self-aggregation or coaggregation with insulin. Hence, ICA512 RESP18HD likely exerts its condensing activity at early stages of granulogenesis along the secretory pathway, i.e. prior to that of other granule cargoes.

The coaggregation of ICA512 RESP18HD and insulin takes place at very low protein concentrations, under $\mathrm{pH}$ and temperature conditions close to physiological, and with no external 

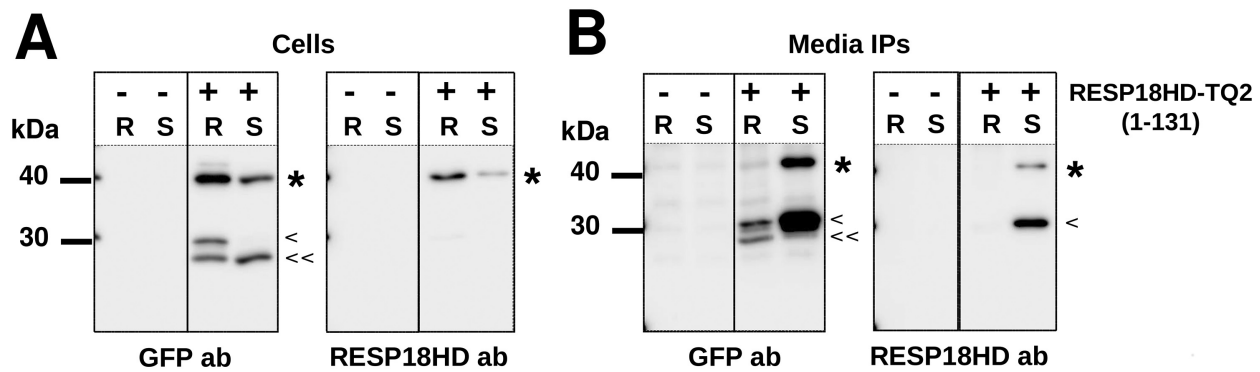

Figure 7. ICA512 RESP18HD-TQ2 processing in INS-1 cells. Resting $(R)$ and glucose stimulated $(S)$ conditions were assayed. Immunoblotting was performed using mouse anti-GFP or anti-ICA512 RESP18HD antibodies. A, cell lysates. B, culture media proteins immunoprecipitated with a goat anti-GFP antibody. The amount of ICA512 RESP18HD-TQ2 $(\approx 40 \mathrm{kDa}$; asterisks) was reduced in stimulated compared with resting cells. The opposite applied to media immunoprecipitates. This behavior is consistent with regulated secretion of ICA512 RESP18HD-TQ2. Remarkably, a single fragment of $\approx 30 \mathrm{kDa}$ (arrowhead) comprising a short C-terminal sequence of ICA512 RESP18HD preceding TQ2 was highly enriched in the culture media from stimulated cells, implying that the proteolysis of the intact $40-\mathrm{kDa}$ fragment is coupled to its secretion. Other proteolytic fragments of $\approx 27 \mathrm{kDa}$ (double arrowheads) did not react with the anti-ICA512 RESP18HD antibody $(a b)$.

physical stress (shearing, stirring, or heating). Under these conditions, isolated ICA512 RESP18HD and insulin per se do not aggregate appreciably and exhibit a moderate and low degree of oligomerization, respectively $(24,47)$. Thus, proper conditions for coaggregation of insulin and ICA512 RESP18HD are likely to evolve in vivo.

Another important finding is that $\mathrm{Zn}^{2+}$ does not inhibit ICA512 RESP18HD-insulin coaggregation (Fig. 2E). Because $\mathrm{Zn}^{2+}$ inhibits the homophilic aggregation of ICA512 RESP18HD at neutral pH (Fig. $2 B$ ), the lack of effect on the coaggregation with insulin suggests that the reaction is not triggered by previously formed aggregates of ICA512 RESP18HD and, on the contrary, is caused by the interaction of soluble ICA512 RESP18HD and insulin. This behavior also suggests that coaggregation would not be impeded by the high concentrations of $\mathrm{Zn}^{2+}$ present in the SG of $\beta$-cells. However, the coaggregation of ICA512 RESP18HD and insulin may be resolved upon their exposure to the very acidic $\mathrm{pH}$ of mature SGs (Fig. 2, D and F). Moreover, the observation that amylin inhibits the coaggregation of ICA512 RESP18HD and insulin (Fig. 2G) reinforces the idea of an interaction between two soluble partners that results in mutual insolubility, for amylin is known to interact directly with soluble insulin and impair its aggregation (38).

Several stable, soluble, and well-characterized proteins were shown to coaggregate if incubated at their melting temperature. This indicates that partially folded states are involved in coaggregation (48). ICA512 RESP18HD is known to be partially unfolded under our experimental conditions. Insulin, in contrast, is monomeric and folded. However, monomeric insulin is less stable than hexameric insulin and has a greater tendency to populate partially folded states (49). Thus, if coaggregation of ICA512 RESP18HD and insulin requires two partially unfolded partners, ICA512 RESP18HD might act shifting the equilibrium of monomeric insulin toward a partially folded state.

Our findings buttress the idea that one of the main mechanisms involved in targeting and regulated secretion is the congregation of mutually interacting proteins in aggregated phases $(26,28)$. However, because of the complexity of the machinery for granule biogenesis, the multiplicity of players, and their redundancy, an essential role of ICA512 RESP18HD is unlikely. Proof of this is shown in mice with genetic deletion of ICA512 and phogrin, two proteins with a RESP18 domain, and SG stores are reduced but not abolished (6).
It is possible that the properties of ICA512 RESP18HD are modulated through interactions with the remaining ICA512 NTF sequence. Unfortunately, pure recombinant variants of the entire NTF domain (Fig. 1A) could not be prepared due to expression and solubility difficulties (data not shown), which impeded in vitro assessment of this possibility. In vivo assays, however, are tedious due to the complexity of post-translational processing of the NTF domain, including its proteolytic cleavage and $O$-glycosylation. ${ }^{6}$ Moreover, the IDR region in ICA512 RESP18HD is part of larger IDR regions in the ICA512 NTF, which might have a bearing in the aggregation behavior of the ICA512 TMF as a whole. However, the ICA512 RESP18HD sequence by itself contains sufficient information to direct GFP and its variants to insulin SGs $(20,24,35)$, which justify using the information gathered studying ICA512 RESP18HD as a guide for the further characterization of ICA512 NTF in the cellular context.

Coaggregation of ICA512 RESP18HD-insulin in vitro occurs within a few minutes and under very mild conditions, and therefore it is different from typical insulin fibrillation or amyloidogenic reactions, which take days and require physical stress. However, partially folded states and aggregates can evolve toward highly-stable cross- $\beta$-fibrils, and this process is at the core of several misfolding diseases and attracts enormous interest from a practical and theoretical point of view (50).

For its availability in pure form and large quantities, and its tendency to form cross- $\beta$-structure in vitro, insulin is a popular experimental model for the study of fibrillogenesis. Even though insulin fibrils have not been directly linked to any misfolding disease, they have been associated with problems in the manufacturing, storing, and administration of insulin $(50,51)$. In addition, cytotoxic effects of insulin fibrils have been reported in cell cultures (52), thereby opening the possibility that yet to be discovered misfolding disorders directly due to insulin fibrillation might exist.

Predictably, biophysical studies found that insulin fibrillogenesis has much in common with the amyloidogenesis of several proteins associated with misfolding pathologies. The coincidences arise because fibrillation and amyloidogenesis are manifestations of protein folding, a fundamental process in

\footnotetext{
${ }^{6}$ J. M. Torkko, P. L. Toledo, M. R. Ermácora, and M. Solimena, unpublished observations.
} 
biology. For fibrillation to occur, conformational changes must take place, such as the backbone adoption of $\beta$-structure and its association into regular $\beta$-sheets perpendicular to the fibril's long axis.

Ligands interacting with the fibrillation nucleus or with protofibrils may block the formation of cross- $\beta$-structure. Driven by the need of therapeutic agents for amyloidosis, several chemical compounds, peptides, and proteins have been discovered with the potential to stop the progression or even revert fibrillation processes (53).

The discovery in this work that the interaction between ICA512 RESP18HD and insulin results in amorphous coaggregation prompted us to test whether ICA512 RESP18HD fibrillates itself and whether it can induce the fibrillation of insulin.

Unexpectedly, not only ICA512 RESP18HD was unable to fibrillate itself but was also a strong inhibitor of the fibrillation of insulin. These effects were recapitulated with ICA512 RESP18HD90, suggesting that the N-terminal segment of ICA512 RESP18HD is responsible for this inhibition. Because ICA512 RESP18HD90 lacks the C-terminal IDR and does not aggregate per se, its previous aggregation is dispensable for inhibition of insulin fibrillation.

Two previously proposed mechanisms for the inhibition of insulin fibrillation are (a) binding of the inhibitor to a fibrillation-competent partially folded insulin monomer, and $(b)$ direct binding of the inhibitor to the growing fibrils (49). Further studies are needed to define which of these alternatives applies to ICA512 RESP18HD inhibition.

Insulin fibrils, or precursors thereof, have been proposed to affect $\beta$-cells and insulin secretion and circulation. Thus, presumably, an efficient control mechanism keeps in check the insulin fibrillation. This presumption is further sustained by the fact that, despite the high concentrations of insulin in $\beta$-cells and the easiness of insulin fibrillation in vitro, no pathologies directly associated to insulin fibrillation have ever been reported.

A very strong inhibitor of insulin fibrillation could be the very high intragranular concentration of insulin, which, along with the high concentration of $\mathrm{Zn}^{2+}$, stabilizes the hexameric insulin- $\mathrm{Zn}^{2+}$ complex and reduces the concentration of aggregation-prone monomeric insulin.

Amylin, which is present at high concentrations in the SG, may also be a natural inhibitor of insulin aggregation and fibrillogenesis $(54,55)$. Also, a ubiquitous $\mathrm{Ca}^{2+}$-binding protein, nucleobindin-1, similar to calreticulin, was found to inhibit insulin fibrillation, attenuate fibril-induced cell toxicity, and is proposed to act as an insulin chaperone in the control of amyloidogenesis in type 2 diabetes (56).

Moreover, we found that exocytosis of ICA512 RESP18HD is coupled with the proteolysis of its $\mathrm{C}$-terminal IDR. Because this is the region responsible for the condensing activity of ICA512 RESP18HD at $\mathrm{pH}>7.0$, it is tempting to propose that such cleavage is required for preventing detrimental consequences resulting from the aggregation of the protein upon its secretion in the extracellular compartment. The identification of the protease responsible for ICA512 RESP18 HD IDR cleavage and the regulation of this process shall be the topic of future studies.
In conclusion, given the multiplicity of proteins and peptides that interact in the SG, it can be hypothesized that the control mechanism to prevent amyloidogenesis is based in a web of interactions between granular cargo and constitutive proteins. In the context of this complex anti-amyloidogenesis system, ICA512 RESP18HD may play an important role due to its preferential interaction with insulin. However, new in vivo experimental approaches need to be devised to confirm this possibility.

\section{Experimental procedures}

\section{Antibodies, chemicals, and general protocols}

Chemicals were of the purest analytical grade available. Human insulin was a gift from Dr. Nestor Annibali (Denver Farma, Buenos Aires, Argentina) and also purchased from Sigma (91077C). Recombinant human proinsulin extended with $\mathrm{N}$-terminal Met, $\mathrm{His}_{6}$ tag, and Lys was from R\&D Systems (1336-PN). Thioflavin T was from Sigma (T3516).

The novel mouse mAb against human ICA512 RESP18HD was raised with the MPI-CBG antibody facility (Dresden, Germany). Mouse and goat anti-GFP, guinea pig anti-insulin, as well as human anti-ME ICA512 antibodies were described previously (20).

In some experiments, to achieve good resolution in a wide range of molecular weights, SDS-polyacrylamide gels were prepared with two consecutive separating layers of 10 and 17\% acrylamide, respectively.

ICA512 RESP18HD concentration was measured using an absorption coefficient at $280 \mathrm{~nm}$ of 7,450 $\mathrm{M}^{-1} \mathrm{~cm}^{-1}$ (24). Binding of $\mathrm{Zn}^{2+}$ to ICA512 RESP18HD was assessed by filtration through microfilters at a $3-\mathrm{kDa}$ cutoff. $\mathrm{Zn}^{2+}$ concentration was determined colorimetrically, following the formation of a complex with Zincon (SC-25839 Santa Cruz Biotechnology).

CD spectra were collected at $20^{\circ} \mathrm{C}$ on a Jasco 810 spectropolarimeter (Jasco Corp., Tokyo, Japan) as described (57). Steadystate fluorescence measurements were performed on an ISS K2 multifrequency phase fluorometer (ISS, Champaign, IL) equipped with a cell holder connected to a circulating water bath at $20^{\circ} \mathrm{C}$ and with 1.0 -cm cells.

In-gel trypsin digestion of SDS-PAGE excised bands was performed with an In-Gel tryptic digestion kit (Thermo Fisher Scientific). Recovered peptides were subjected to LC-MS/MS with electrospray ionization in an LTQ Orbitrap XL ETD instrument (Thermo Fisher Scientific).

Microscopy images of human EndoC- $\beta \mathrm{H} 1$ cells and pancreatic islet sections were acquired with an Olympus FluoView1000 laser-scanning confocal microscope equipped with a 60 PlanoApo OLSM lens (numerical aperture 1.10) (MPI-CBG, Dresden, Germany). SDS-PAGE image analysis was carried out with ImageJ.

\section{DNA constructs and protein expression}

The pET-9 plasmid for expression of human ICA512 RESP18HD in E. coli was described previously (24). A truncated variant ICA512 RESP18HD90 (residues 35-90) was generated by site-directed mutagenesis (QuikChange, Stratagene) by replacing the codon for residue 91 with a stop codon. Purifica- 


\section{ICA512 RESP18HD condensing and anti-amyloidogenic activity}

tion of ICA512 RESP18HD was previously described (24). A similar protocol was used to purify ICA512 RESP18HD90.

For expression in INS-1 cells, cDNAs encoding ICA512 $\mathrm{N}$-terminal signal peptide sequence and either full (residues 1-131) or a truncated variant of ICA512 RESP18HD (residues 1-124) was generated by PCR and fused in-frame to a sequence encoding TQ2 at their $\mathrm{C}$ termini. TQ2 is a derivative of GFP, and ICA512 RESP18HD-GFP was assessed in our previous work (20). Similarly the cDNAs encoding for both human phogrin ICA512 RESP18HD (residues 1-136) and human Resp18 (residues 1-228) were generated by PCR and fused at their $\mathrm{C}$ termini to TQ2. All constructs were verified by DNA sequencing.

\section{Cell culture and immunocytochemistry}

Cultures of INS-1 insulinoma cells and their exposure to resting and high-glucose stimulation (cell lysate preparation, and culture media immunoprecipitation) were performed as described (20). To harvest resting and stimulation culture media, these were at first pipetted from the cells into $15-\mathrm{ml}$ Falcon tubes, inclusive protease inhibitors (1:100; Sigma), centrifuged briefly to clear the media fractions from any residual cells, and prepared for immunoprecipitation using goat antiGFP antibody essentially as described (20). Human EndoC$\beta \mathrm{H} 1$ cells were cultured in Dulbecco's modified Eagle's medium with $5.5 \mathrm{~mm}$ glucose, 2\% BSA Fraction V, $50 \mu \mathrm{M}$ 2-mercaptoethanol, $10 \mathrm{~mm}$ nicotinamide, $5.5 \mu \mathrm{g} / \mathrm{ml}$ transferrin, $6.7 \mathrm{ng} / \mathrm{ml}$ selenite, 100 units $/ \mathrm{ml}$ penicillin, and $100 \mu \mathrm{g} / \mathrm{ml}$ streptomycin. EndoC $-\beta \mathrm{H} 1$ cell lysates were prepared in $50 \mathrm{~mm}$ HEPES, pH 7.0. EndoC- $\beta \mathrm{H} 1$ cell transfections with esiRNA (Eupheria Biotech, Dresden, Germany) were performed with Dharmafect ${ }^{\mathrm{TM}}$ transfection reagents. Paraffin sections of human pancreatic islets were prepared as described (58). EndoC- $\beta \mathrm{H} 1$ cells and the pancreatic islet sections were immunostained with guinea pig anti-insulin, the novel mouse anti-ICA512 RESP18HD antibody, and the respective Alexa-conjugated secondary antibodies, as described previously $(20,58)$. 4',6-Diamidino-2-phenylindole dilactate was used for nuclei staining.

\section{Aggregation reactions}

Time course of ICA512 RESP18HD aggregation at $20^{\circ} \mathrm{C}$ was followed measuring scattered light as UV absorption at $400 \mathrm{~nm}$. The stock solution of ICA512 RESP18HD was prepared in 25 mM sodium acetate, $\mathrm{pH} 4.5$. The reaction was started adding ICA512 RESP18HD to a final concentration of $2 \mu \mathrm{M}$ to $25 \mathrm{~mm}$ HEPES adjusted to the indicated $\mathrm{pH}$ in the 4.5-7.4 range by adding acetic acid or sodium hydroxide. To test the effect of different metals and EDTA, these were added to the reaction buffer, and the $\mathrm{pH}$ was readjusted to the desired value before starting the measurements.

Coaggregation of ICA512 RESP18HD with insulin was assayed by light scattering as indicated above. The reaction was started adding insulin to ICA512 RESP18HD solutions, resulting in 8 and $2 \mu \mathrm{m}$ final concentration, respectively. Different additives to the basic reaction were as described under "Results."

\section{ThT fluorescence assay}

To induce the formation of insulin amyloid cross- $\beta$-fibrils, $20 \mu \mathrm{m}$ insulin in $100 \mathrm{~mm}$ HEPES, pH 6.8, was incubated for $1 \mathrm{~h}$ at $60{ }^{\circ} \mathrm{C}$ with a stirring bar rotating at $150 \mathrm{rpm}$. At time 0 and at the end of the incubation, samples were withdraw, diluted to 2 $\mu \mathrm{M}$, and added to $2 \mu \mathrm{M}$ ThT in the same buffer for immediate fluorescence measurement. Excitation and emission wavelength were 440 and $480 \mathrm{~nm}$, respectively. ICA512 RESP18HD and ICA512 RESP18HD-insulin aggregates formed by incubation at $20^{\circ} \mathrm{C}$ were directly assayed for ThT fluorescence without heating and stirring treatment.

\section{Separation of aggregate proteins by centrifugation and SDS-PAGE}

The formation of higher-order protein aggregates was analyzed by centrifugation and SDS-PAGE. Typically, $10 \mu \mathrm{M}$ ICA512 RESP18HD with or without other proteins at a similar concentration was incubated for $30 \mathrm{~min}$ in $100 \mu \mathrm{l}$ of $100 \mathrm{~mm}$ HEPES, pH 6.8. The samples were then spun for 5 min at 13,000 $\mathrm{rpm}$ in a microcentrifuge. The supernatant and pellet fractions were TCA-precipitated, and pellets were dissolved in SDSPAGE sample buffer. Samples were heated for $5 \mathrm{~min}$ at $60^{\circ} \mathrm{C}$ in the presence of $100 \mathrm{~mm}$ DTT before loading into the SDS-polyacrylamide gel.

\section{TEM}

ICA512 RESP18HD aggregates, prepared as described above after incubation alone or together with insulin, were pipetted onto mesh grids equipped with a carbon film and incubated for $4 \mathrm{~min}$. Afterward, excess fluid was removed, and the grids were incubated with $1 \%$ uranyl formate solution for $30 \mathrm{~s}$. After removal of most of the staining solution, the grids were airdried. TEM images were acquired with a Tecnai 12 BioTwin transmission electron microscope (FEI Co.) operated at $120 \mathrm{kV}$ equipped with a bottom-mount $2 \times 2 \mathrm{~K}$ F214 CCD camera (TVIPS).

Author contributions-P. L. T., J. M. T., A. M., C. W., A. S., M. S., and M. R. E. investigation; P. L. T., J. M. T., A. M., M. S., and M. R. E. visualization; P. L. T., J. M. T., M. S., and M. R. E. methodology; P. L. T., J. M. T., A. M., M. S., and M. R. E. writing-review and editing; J.M. T., M.S., and M. R. E. validation; J. M. T., M.S., and M. R. E. writing-original draft; M. S. and M. R. E. conceptualization; M. S. and M. R. E. resources; M. S. and M. R. E. formal analysis; M. S. and M. R. E. supervision; M. S. and M. R. E. funding acquisition.

Acknowledgments-The German Center for Diabetes Research (DZD) is supported by the German Ministry for Education and Research (BMBF). The Innovative Medicines Initiative 2 Joint Undertaking receives support from the European Union's Horizon 2020 research and innovation programme and EFPIA. We thank Daniela Richter for the immunostaining of human pancreatic tissue sections; Jürgen Weitz, Marius Distler, and Nicole Radisch for the provision of surgical pancreatic specimens; Patrick Keller for antibody production at MPI-CBG; Marc Gentzel (Biotec, Dresden) for MS analysis, and Katja Pfriem for outstanding administrative assistance. 


\section{References}

1. Andersen, J. N., Mortensen, O. H., Peters, G. H., Drake, P. G., Iversen, L. F., Olsen, O. H., Jansen, P. G., Andersen, H. S., Tonks, N. K., and Møller, N. P. (2001) Structural and evolutionary relationships among protein-tyrosine phosphatase domains. Mol. Cell. Biol. 21, 7117-7136 CrossRef Medline

2. Wasmeier, C., and Hutton, J. C. (1996) Molecular cloning of phogrin, a protein-tyrosine phosphatase homologue localized to insulin secretory granule membranes. J. Biol. Chem. 271, 18161-18170 CrossRef Medline

3. Solimena, M., Dirkx, R., Jr., Hermel, J. M., Pleasic-Williams, S., Shapiro, J. A., Caron, L., and Rabin, D. U. (1996) ICA 512, an autoantigen of type I diabetes, is an intrinsic membrane protein of neurosecretory granules. $E M B O$ J. 15, 2102-2114 CrossRef Medline

4. Saeki, K., Zhu, M., Kubosaki, A., Xie, J., Lan, M. S., and Notkins, A. L. (2002) Targeted disruption of the protein-tyrosine phosphatase-like molecule IA-2 results in alterations in glucose tolerance tests and insulin secretion. Diabetes 51, 1842-1850 CrossRef Medline

5. Kubosaki, A., Gross, S., Miura, J., Saeki, K., Zhu, M., Nakamura, S., Hendriks, W., and Notkins, A. L. (2004) Targeted disruption of the IA-2 $\beta$ gene causes glucose intolerance and impairs insulin secretion but does not prevent the development of diabetes in NOD mice. Diabetes 53, 1684-1691 CrossRef Medline

6. Kubosaki, A., Nakamura, S., and Notkins, A. L. (2005) Dense core vesicle proteins IA-2 and IA-2 $\beta$ : metabolic alterations in double knockout mice. Diabetes 54, S46-S51 CrossRef Medline

7. Trajkovski, M., Mziaut, H., Altkrüger, A., Ouwendijk, J., Knoch, K.-P., Müller, S., and Solimena, M. (2004) Nuclear translocation of an ICA512 cytosolic fragment couples granule exocytosis and insulin expression in $\beta$-cells. J. Cell Biol. 167, 1063-1074 CrossRef Medline

8. Mziaut, H., Trajkovski, M., Kersting, S., Ehninger, A., Altkrüger, A., Lemaitre, R. P., Schmidt, D., Saeger, H. D., Lee, M. S., Drechsel, D. N., Müller, S., and Solimena, M. (2006) Synergy of glucose and growth hormone signalling in islet cells through ICA512 and STAT5. Nat. Cell Biol. 8, 435-445 CrossRef Medline

9. Schubert, S., Knoch, K.-P., Ouwendijk, J., Mohammed, S., Bodrov, Y., Jäger, M., Altkrüger, A., Wegbrod, C., Adams, M. E., Kim, Y., Froehner, S. C., Jensen, O. N., Kalaidzidis, Y., and Solimena, M. (2010) $\beta 2$-Syntrophin is a Cdk5 substrate that restrains the motility of insulin secretory granules. PLoS ONE 5, e12929 CrossRef Medline

10. Torii, S. (2009) Expression and function of IA-2 family proteins, unique neuroendocrine-specific protein-tyrosine phosphatases. Endocr. J. 56, 639-648 CrossRef Medline

11. Trajkovski, M., Mziaut, H., Schubert, S., Kalaidzidis, Y., Altkrüger, A., and Solimena, M. (2008) Regulation of insulin granule turnover in pancreatic $\beta$-cells by cleaved ICA512. J. Biol. Chem. 283, 33719-33729 CrossRef Medline

12. Ort, T., Voronov, S., Guo, J., Zawalich, K., Froehner, S. C., Zawalich, W., and Solimena, M. (2001) Dephosphorylation of $\beta 2$-syntrophin and $\mathrm{Ca}^{2+}$ / $\mu$-calpain-mediated cleavage of ICA512 upon stimulation of insulin secretion. EMBO J. 20, 4013-4023 CrossRef Medline

13. Mziaut, H., Mulligan, B., Hoboth, P., Otto, O., Ivanova, A., Herbig, M., Schumann, D., Hildebrandt, T., Dehghany, J., Sönmez, A., Münster, C., Meyer-Hermann, M., Guck, J., Kalaidzidis, Y., and Solimena, M. (2016) The F-actin modifier villin regulates insulin granule dynamics and exocytosis downstream of islet cell autoantigen 512. Mol. Metab. 5, 656-668 CrossRef Medline

14. Mziaut, H., Kersting, S., Knoch, K.-P., Fan, W.-H., Trajkovski, M., Erdmann, K., Bergert, H., Ehehalt, F., Saeger, H.-D., and Solimena, M. (2008) ICA512 signaling enhances pancreatic beta-cell proliferation by regulating cyclins D through STATs. Proc. Natl. Acad. Sci. U.S.A. 105, 674-679 CrossRef Medline

15. Liu, Y., Mziaut, H., Ivanova, A., and Solimena, M. (2009) $\beta$-cells at the crossroads: choosing between insulin granule production and proliferation. Diabetes Obes. Metab. 11, 54-64 CrossRef Medline

16. Bork, P., and Patthy, L. (1995) The SEA module: a new extracellular domain associated with O-glycosylation. Protein Sci. 4, 1421-1425 CrossRef Medline
17. Primo, M. E., Sica, M. P., Risso, V. A., Poskus, E., and Ermácora, M. R. (2006) Expression and physicochemical characterization of an extracellular segment of the receptor protein-tyrosine phosphatase IA-2. Biochim. Biophys. Acta 1764, 174-181 CrossRef Medline

18. Primo, M. E., Klinke, S., Sica, M. P., Goldbaum, F. A., Jakoncic, J., Poskus, E., and Ermácora, M. R. (2008) Structure of the mature ectodomain of the human receptor-type protein-tyrosine phosphatase IA-2. J. Biol. Chem. 283, 4674-4681 CrossRef Medline

19. Primo, M. E., Jakoncic, J., Noguera, M. E., Risso, V. A., Sosa, L., Sica, M. P., Solimena, M., Poskus, E., and Ermácora, M. R. (2011) Protein-protein interactions in crystals of the human receptor-type protein-tyrosine phosphatase ICA512 ectodomain. PLoS ONE 6, e24191 CrossRef Medline

20. Torkko, J. M., Primo, M. E., Dirkx, R., Friedrich, A., Viehrig, A., Vergari, E., Borgonovo, B., Sönmez, A., Wegbrod, C., Lachnit, M., Münster, C., Sica, M. P., Ermácora, M. R., and Solimena, M. (2015) Stability of pro-ICA512/ IA-2 and its targeting to insulin secretory granules require $\beta 4$-sheet-mediated dimerization of its ectodomain in the endoplasmic reticulum. Mol. Cell. Biol. 35, 914-927 CrossRef Medline

21. Noguera, M. E., Primo, M. E., Jakoncic, J., Poskus, E., Solimena, M., and Ermácora, M. R. (2015) X-ray structure of the mature ectodomain of phogrin. J. Struct. Funct. Genomics 16, 1-9 CrossRef Medline

22. Noguera, M. E., Primo, M. E., Sosa, L. N., Risso, V. A., Poskus, E., and Ermácora, M. R. (2013) Biophysical characterization of the membraneproximal ectodomain of the receptor-type protein-tyrosine phosphatase phogrin. Protein Pept. Lett. 20, 1009-1017 CrossRef Medline

23. Zhang, G., Hirai, H., Cai, T., Miura, J., Yu, P., Huang, H., Schiller, M. R., Swaim, W. D., Leapman, R. D., and Notkins, A. L. (2007) RESP18, a homolog of the luminal domain IA-2, is found in dense core vesicles in pancreatic islet cells and is induced by high glucose. J. Endocrinol. 195, 313-321 CrossRef Medline

24. Sosa, L., Torkko, J. M., Primo, M. E., Llovera, R. E., Toledo, P. L., Rios, A. S., Flecha, F. L., Trabucchi, A., Valdez, S. N., Poskus, E., Solimena, M., and Ermácora, M. R. (2016) Biochemical, biophysical, and functional properties of ICA512/IA-2 RESP18 homology domain. Biochim. Biophys. Acta 1864, 511-522 CrossRef Medline

25. Beuret, N., Hasler, F., Prescianotto-Baschong, C., Birk, J., Rutishauser, J., and Spiess, M. (2017) Amyloid-like aggregation of provasopressin in diabetes insipidus and secretory granule sorting. BMC Biol. 15, 5 CrossRef Medline

26. Dannies, P. S. (2012) Prolactin and growth hormone aggregates in secretory granules: the need to understand the structure of the aggregate. Endocr. Rev. 33, 254-270 CrossRef Medline

27. Dikeakos, J. D., and Reudelhuber, T. L. (2007) Sending proteins to dense core secretory granules: still a lot to sort out. J. Cell Biol. 177, 191-196 CrossRef Medline

28. Arvan, P., and Halban, P. A. (2004) Sorting ourselves out: seeking consensus on trafficking in the beta-cell. Traffic 5, 53-61 CrossRef Medline

29. Wheeler, R. J., and Hyman, A. A. (2018) Controlling compartmentalization by non-membrane-bound organelles. Philos. Trans. R. Soc. B Biol. Sci. 373, 20170193 CrossRef

30. Shin, Y., and Brangwynne, C. P. (2017) Liquid phase condensation in cell physiology and disease. Science 357, eaaf4382 CrossRef Medline

31. Wegmann, S., Eftekharzadeh, B., Tepper, K., Zoltowska, K. M., Bennett, R. E., Dujardin, S., Laskowski, P. R., MacKenzie, D., Kamath, T., Commins, C., Vanderburg, C., Roe, A. D., Fan, Z., Molliex, A. M., Hernandez-Vega, A., et al. (2018) Tau protein liquid-liquid phase separation can initiate tau aggregation. EMBO J. 37, e98049 CrossRef Medline

32. Aguzzi, A., and Altmeyer, M. (2016) Phase separation: linking cellular compartmentalization to disease. Trends Cell Biol. 26, 547-558 CrossRef Medline

33. Horvath, I., and Wittung-Stafshede, P. (2016) Cross-talk between amyloidogenic proteins in type-2 diabetes and Parkinson's disease. Proc. Natl. Acad. Sci. U.S.A. 113, 12473-12477 CrossRef Medline

34. Kahn, S. E., Andrikopoulos, S., and Verchere, C. B. (1999) Islet amyloid: a long-recognized but underappreciated pathological feature of type 2 diabetes. Diabetes 48, 241-253 CrossRef Medline 


\section{ICA512 RESP18HD condensing and anti-amyloidogenic activity}

35. Neukam, M., Soenmez, A., and Solimena, M. (2017) FLIM-based pH measurements reveal incretin-induced rejuvenation of aged insulin secretory granules. bioRxiv CrossRef

36. Foster, M. C., Leapman, R. D., Li, M. X., and Atwater, I. (1993) Elemental composition of secretory granules in pancreatic islets of Langerhans. Biophys. J. 64, 525-532 CrossRef Medline

37. Tsumoto, K., Umetsu, M., Kumagai, I., Ejima, D., Philo, J. S., and Arakawa, T. (2004) Role of arginine in protein refolding, solubilization, and purification. Biotechnol. Prog. 20, 1301-1308 CrossRef Medline

38. Susa, A. C., Wu, C., Bernstein, S. L., Dupuis, N. F., Wang, H., Raleigh, D. P., Shea, J.-E., and Bowers, M. T. (2014) Defining the molecular basis of amyloid inhibitors: human islet amyloid polypeptide-insulin interactions. J. Am. Chem. Soc. 136, 12912-12919 CrossRef Medline

39. Hutton, J. C. (1984) Secretory granules. Experientia 40, 1091-1098 CrossRef Medline

40. Wang, Y., Lomakin, A., Latypov, R. F., and Benedek, G. B. (2011) Phase separation in solutions of monoclonal antibodies and the effect of human serum albumin. Proc. Natl. Acad. Sci. U.S.A. 108, 16606-16611 CrossRef Medline

41. Mawhinney, M. T., Williams, T. L., Hart, J. L., Taheri, M. L., and Urbanc, B. (2017) Elucidation of insulin assembly at acidic and neutral pH: characterization of low molecular weight oligomers. Proteins 85, 2096-2110 CrossRef Medline

42. Ravassard, P., Hazhouz, Y., Pechberty, S., Bricout-Neveu, E., Armanet, M., Czernichow, P., and Scharfmann, R. (2011) A genetically engineered human pancreatic $\beta$ cell line exhibiting glucose-inducible insulin secretion. J. Clin. Invest. 121, 3589-3597 CrossRef Medline

43. Obradovic, Z., Peng, K., Vucetic, S., Radivojac, P., and Dunker, A. K. (2005) Exploiting heterogeneous sequence properties improves prediction of protein disorder. Proteins 61, S176-S182 CrossRef Medline

44. Mészáros, B., Erdos, G., and Dosztányi, Z. (2018) IUPred2A: context-dependent prediction of protein disorder as a function of redox state and protein binding. Nucleic Acids Res. 46, W329-W337 CrossRef Medline

45. Khmelinskii, A., Meurer, M., Ho, C.-T., Besenbeck, B., Füller, J., Lemberg, M. K., Bukau, B., Mogk, A., and Knop, M. (2016) Incomplete proteasomal degradation of green fluorescent proteins in the context of tandem fluorescent protein timers. Mol. Biol. Cell 27, 360-370 CrossRef Medline

46. Rindler, M. J. (1998) Carboxypeptidase E, a peripheral membrane protein implicated in the targeting of hormones to secretory granules, co-aggregates with granule content proteins at acidic pH. J. Biol. Chem. 273, 31180 -31185 CrossRef Medline

47. Tantipolphan, R., Romeijn, S., Engelsman Jden Torosantucci, R., Rasmussen, T., and Jiskoot, W. (2010) Elution behavior of insulin on high perfor- mance size exclusion chromatography at neutral pH. Pharm. Biomed. Anal. 52, 195-202 CrossRef

48. Dubey, K., Anand, B. G., Temgire, M. K., and Kar, K. (2014) Evidence of rapid coaggregation of globular proteins during amyloid formation. Biochemistry 53, 8001-8004 CrossRef Medline

49. Ludwig, D. B., Webb, J. N., Fernández, C., Carpenter, J. F., and Randolph, T. W. (2011) Quaternary conformational stability: the effect of reversible self-association on the fibrillation of two insulin analogs. Biotechnol. Bioeng. 108, 2359-2370 CrossRef Medline

50. Groenning, M., Frokjaer, S., and Vestergaard, B. (2009) Formation mechanism of insulin fibrils and structural aspects of the insulin fibrillation process. Curr. Protein Pept. Sci. 10, 509-528 CrossRef Medline

51. Nilsson, M. R. (2016) Insulin amyloid at injection sites of patients with diabetes. Amyloid 23, 139-147 CrossRef Medline

52. Bystrenova, E., Bednarikova, Z., Barbalinardo, M., Valle, F., Gazova, Z., and Biscarini, F. (2018) Insulin amyloid structures and their influence on neural cells. Colloids Surf. B Biointerfaces 161, 177-182 CrossRef Medline

53. Ratha, B. N., Ghosh, A., Brender, J. R., Gayen, N., Ilyas, H., Neeraja, C., Das, K. P., Mandal, A. K., and Bhunia, A. (2016) Inhibition of insulin amyloid fibrillation by a novel amphipathic heptapeptide: mechanistic details studied by spectroscopy in combination with microscopy. J. Biol. Chem. 291, 23545-23556 CrossRef Medline

54. Gilead, S., Wolfenson, H., and Gazit, E. (2006) Molecular mapping of the recognition interface between the islet amyloid polypeptide and insulin. Angew. Chemie Int. Ed. Engl. 118, 6626-6630 CrossRef

55. Cui, W., Ma, J. W., Lei, P., Wu, W. H., Yu, Y. P., Xiang, Y., Tong, A. J., Zhao, Y. F., and Li, Y. M. (2009) Insulin is a kinetic but not a thermodynamic inhibitor of amylin aggregation. FEBS J. 276, 3365-3371 CrossRef Medline

56. Kanuru, M., and Aradhyam, G. K. (2017) Chaperone-like activity of calnuc prevents amyloid aggregation. Biochemistry 56, 149-159 CrossRef Medline

57. Santos, J., Gebhard, L. G., Risso, V. A., Ferreyra, R. G., Rossi, J. P., and Ermácora, M. R. (2004) Folding of an abridged $\beta$-lactamase. Biochemistry 43, 1715-1723 CrossRef Medline

58. Solimena, M., Schulte, A. M., Marselli, L., Ehehalt, F., Richter, D., Kleeberg, M., Mziaut, H., Knoch, K.-P., Parnis, J., Bugliani, M., Siddiq, A., Jörns, A., Burdet, F., Liechti, R., Suleiman, M., et al. (2018) Systems biology of the IMIDIA biobank from organ donors and pancreatectomised patients defines a novel transcriptomic signature of islets from individuals with type 2 diabetes. Diabetologia 61, 641-657 CrossRef Medline 